The International Journal of Human Resource Management, Volume 20, Issue 2, 2009, Pages 301-320

Exposing the Symbolic Capital of International Assignments

Dr Noeleen Doherty

Dr Michael Dickmann

Cranfield School of Management

Cranfield University

Cranfield

Bedford

MK 43 OAL

E-mail: noeleen.doherty@cranfield.ac.uk

Tel: $+\mathbf{4 4 ( 0 ) 1 2 3 4 7 5 1 1 2 2}$

Fax: +44(0)1234 751806 


\title{
Exposing the Symbolic Capital of International Assignments
}

\begin{abstract}
This paper explores the symbolic capital attributed to international assignments. The concept of symbolic capital has been proposed as pivotal in the development and utility of career capital. Although the use of international assignments (IAs) remains a key strategy for global organisations and has been posed as a career advantage for individuals, there is a lack of research which attempts to explore the accumulation and utilization of the capital acquired from such experiences.
\end{abstract}

This paper contributes to the current debate on international careers by examining the symbolic capital of international assignments as a key element in international careers. Data from a case study within the financial services sector are used to explore some of the recently highlighted challenges of implementing and experiencing international assignment programmes. Areas for further exploration are proposed.

Key Words

Symbolic capital, international assignments, career capital, career development 


\section{Exposing the Symbolic Capital of International Assignments}

A capital perspective on international assignments is important since the focus in research on expatriate careers has shifted away from expatriate adjustment models (Black and Gregersen, 1992) to work which considers individual's experiences within broader frames of reference (for example Welch, 2003; Cerdin and Dubouloy, 2004) and in particular the career capital of IAs and the return on investment in expatriation (Dickmann and Harris, 2005; McNulty and Tharenou, 2004). There has also been a move towards the development of an integrated theoretical framework which takes a capital perspective to facilitate a comprehensive view on context and the numerous levels of analysis which frame an understanding of careers and in particular careers in an international context (Mayrhofer et al, 2004a; Mayrhofer, et al, 2004b).

This paper explores the concept of symbolic capital in understanding international assignments and attempts to expose the role symbolic capital plays in shaping career behaviours and career management, from individual and organisational perspectives.

The objectives of the paper are twofold:

- From an exploratory study, describe the symbolic capital attributed to IAs by organisational representatives and by individuals who have been on assignment and remain within the organisation 
- Explore how the concept of symbolic capital can enhance our understanding of international assignments and build propositions to be researched within this theoretical framework

\section{The Role and Significance of International Assignments}

Traditional expatriation remains the choice of many global companies paradoxically at a time when employees have become increasingly discerning about accepting an expatriate assignment (Borstorff, Harris, Field and Giles, 1997; Stahl and Cerdin, 2004). Many authors have endorsed the importance of international working as a key way of gaining competitive advantage and benefiting the organisation (Sparrow, Brewster and Harris, 2004) and as an important mechanism for individual development (Edstrom and Galbraith 1977). Thus the rationale for using international assignments can be viewed as reciprocal, with potentially positive outcomes for both organisation and individual (Larsen, 2004).

However, research indicates that there are numerous issues involved in the management of expatriation. Individuals are increasingly uneasy about accepting an assignment, they do not fit easily back into the organisation on return or enjoy the expected career benefits of having worked abroad. In fact attrition is often high (e.g. Black and Gregersen, 1999) and there can be a lack of job security or career progression on return (Doherty and Dickmann, 2007; Dickmann, Doherty, Mills and Brewster, 2008, 
forthcoming) often prompting exit to another company (Suutari and Brewster, 2000; 2003). From the organisational perspective, despite considerable investment of both time and money, few companies track individuals on repatriation and hence have little information on which to assess any return. This often means missed opportunities to reap the potential developmental or longer-term benefits of the expatriation experience (McNulty and Tharenou, 2004, Suutari and Taka, 2004).

Carpenter, Sanders and Gregersen, (2000) argued that IA experience at the top of the organisation can make a bottom line difference, since this capability characterizes competitive advantage in being rare, valuable and hard to imitate. It has also been argued that organisations should expect the international experience of top management to provide "substantive and symbolic benefits to the firm", since "symbolically, IA experience may communicate to other employees that accepting such assignments is highly valued by the firm" (Carpenter, Sanders and Reverse, 2001:278/9).

In support of this notion Lazarova and Caligiuri (2001) found that repatriates positively rated visible signs that the company values overseas experience. Company wide appreciation of global experience and career planning in recognition of the career benefit of international experience were considered the two most important elements in international human resource management practices for managing repatriation. The authors suggested that the company leadership must aggressively demonstrate that it values international expertise and show that such experience is 
career enhancing and prestigious, by capitalizing on the expertise the expatriates have developed, when they return. High turnover among repatriates may signal to other employees that international working may have a negative impact on career.

These studies draw attention to the symbolic nature of international working. Larçon and Reitter (1984) suggested that symbolic products are the visible manifestations of a common organisational imagery - the sets of assumptions, impulses and values which direct (but not necessarily consciously) behaviours within organisations. Therefore, symbols can significantly influence the behaviors of an organisation's members (Johnson, 1990; Moingeon and Ramanantsoa, 1997)

Many of the apparent paradoxes of international working have been studied in isolation or have remained obscured, since there is a lack of a comprehensive frame of reference in the study of careers within the international context (Thomas, Lazarova and Inkson, 2005) and a perpetuation of unitary frames of analysis (Dany, Mallon and Arthur, 2003). The ideas of Bourdieu (1986) and the concept of symbolic capital constitute a broad framework through which international working can be examined. First the concept of symbolic capital is presented and then it is applied to an understanding of the IA experience. 


\section{Symbolic Capital}

According to Bourdieu (1998) symbolic capital is the perception, understanding and recognition of the value attributed to any of the other forms of capital (social, cultural and economic). Symbolic capital is embodied in prestige, renown, reputation and personal authority (Bourdieu, 1998). Bourdieu (1977) suggested that social and cultural capitals are converted to symbolic capital. Symbolic capital is identified as the combination of the other forms of capital and is fundamental to their use in that it facilitates the conversion of social or cultural capital to economic capital (Gergs, 2003).

Symbolic capital resides in individuals, however, Bourdieu (1986) defined the production of symbolic capital as a socially constructed process through which other forms of capital become accepted, socially recognized as legitimate and considered valuable. The recognition of symbolic capital assumes a shared understanding and shared meaning by other actors of what constitutes value and therefore what is considered legitimate, valid and useful. Thus, symbolic capital refers to the ways in which one is valued by others. Bourdieu (1998) used the example of honour in Mediterranean societies as a typical form of symbolic capital, where honour only has currency through the representation that others have of it and to the extent that there are shared beliefs about what are considered honorable or dishonorable patterns of behaviour. 
Everett (2002) suggested that "the other forms of capital are converted to symbolic capital the instant they are deemed legitimate and it is only in the form of symbolic capital that the ultimate base of power - wealth - can exert power and exert it durably" (p63). This reference to the power dynamic within and between groups brings to light the hidden forms of domination that are consciously and unconsciously reproduced in everyday life and highlights competition for power and prestige.

Bourdieu's notion of power is relational, as actors constantly strive to amass capital. Symbolic capital is based on perceptions and appreciation; the beliefs that are shared by social agents. According to Bourdieu (1977) the real function of symbolic capital is to secure the reproduction of power relations and to facilitate the co-ordination of socio-economic life. In certain cases this means obedience or submission (domination) by one set of social agents over another and as suggested by Uhliřr (1998) the possession of symbolic capital empowers agents to impose a vision on others minds. Those recognized as legitimate and accepted can institute taken for-granted ways of doing things which then become accepted as common practice.

Fuller and Tian (2006) argued that symbolic capital is defined through its function of mediating power through prestige. Özbilgin and Tatli (2005) indicated that these concepts can facilitate the linking of agency and structure by situating individuals within the context of the organisation and 
in their relations to each other and situating the organisation and culture within the context of society and history. This is particularly relevant to understanding the expatriate career. Inkson, Arthur, Pringle and Barry (1997) reflected on the rather demeaning powerlessness (author's emphasis) attributed to the expatriate / repatriate in the process (p354). Expatriates they argued are often positioned as being at the mercy of organisational processes which determine the outcomes of an assignment. However, individuals quote their personal development rather than company results and the desire to experience different cultures as the key motivations for taking an IA. This highlights a tension within the practice of expatriation which focuses on the power relations between the expatriate/repatriate and organisational representatives.

\section{Career Capital}

Career development has been posed as a two-way interaction between the individual and the organisation and involves matching expectations concerning performance and reward (increased productivity and long term effectiveness for the organisation and job satisfaction and personal development for the individual). In the context of international careers the literature has supported the notion that IAs fulfil an important strategic organisational role and implicitly a developmental need for individuals (Dowling, Welch and Schuler, 1999; Edstrom and Galbraith 1977). Indeed, 
career advancement has been identified as a powerful motivator to accept an IA (Welch, 2003).

Such work suggests that for IAs the expectations of financial and career benefits are important elements of the psychological contract (Guest, 1998, Herriot, Manning and Kidd, 1997, Rousseau, 1995). Cullinane and Dundon (2006) suggested that the psychological contract concept should be recognized as "a social exchange interaction "(119) which should take into account the sets of values and norms within the organisational context. Symbolic capital provides a lens through which the social exchange of an IA can be considered, facilitating an analysis of the inputs and outcomes of the psychological contract which are commonly accepted as legitimate and acknowledged by the collective. These outcomes could potentially be the authority, knowledge, prestige and reputation acquired and commonly recognized as a consequence of being an international assignee.

According to Bourdieu (1998) symbolic acts always assume that two parties have identical categories of perception and appreciation. Özbilgin and Tatli (2005) pointed out that symbolic capital embodies both subjective and objective properties, implying both a personal, individual view alongside a collective view formed through a shared meaning of value and worth. For example, citations are an index of symbolic capital in the academic profession as they bestow legitimacy on the individual signaling an acceptance of the individual's contribution to the academic discipline by 
peers (Cronin and Shaw, 2002). Citations provide authentication and legitimacy and hold considerable symbolic capital as a signal of an individual's standing within the academic community.

Crucially symbolic capital operates as a limited resource in which prestige is defined and distinction reasserted through the division and exclusion of particular groups (Flint and Rowlands, 2003). The potential of some groups within the organisational context to acquire symbolic capital may be greater than others. For example, those in graduate or fast track recruitment schemes used for the development of the future top management of the organisation may hold greater symbolic capital than other groups of employees within the organisation. The use of IA is often a part of such development programmes and may therefore be symbolically powerful.

The process of recognition of symbolic capital reflects the economic system's assumptions about the usefulness of career capital in economic terms. The networks an individual had built in a former career may hold legitimacy, and therefore symbolic capital, in a managerial career. But, this social capital is legitimate and holds symbolic capital only in so far as the networks are recognized as useful and applicable within the rules of the managerial field. 


\section{Career Capital as Symbolic Capital}

lellatchitch, Mayrhofer and Meyer, (2003) outlined the making of career capital. They suggested that the process of internal recognition, that is recognition by other actors within the career field and the rules of the field (e.g. how people gain promotion) contributes to the perceived symbolic capital of career. The process of external recognition reflects the economic system's assumptions about the usefulness of career capital in economic terms. Therefore, symbolic capital mediates the relationship between the career investment made by the individual and the career capital realised. The economic value of this career capital is ultimately determined by the economic system.

\section{Exploring Symbolic Capital: The Research Focus}

Fuller \& Tian (2006) in the study of socially responsible acts suggested that acts can create symbolic capital; acts may in themselves be symbolic or acts are symbolized in a way that signals and increases prestige. In this study we explore whether IAs can create symbolic capital; whether IAs are symbolic acts or IAs are symbolized as prestigious and further facilitate the development of prestige through the development of career capital (subjectively as perceptions of positive outcomes and objectively as promotion and career advancement). The process of recognition will be impacted by the organisational stance embodied formally (objectively) in 
the strategies, policies and practices used to initiate, maintain, manage and support international assignees. Senior managers' perceptions of international mobility and assignees perceptions of their personal experience also influence the informal (subjective) recognition of the symbolic capital of IAs. Therefore, we propose that to describe the symbolic capital of IAs requires an analysis of organisational perspectives (documented strategy and policy and the perceived legitimacy of IA by senior management, work colleagues and peers) as well as the individual assignees' perceptions of IA (the perceived symbolic capital of IA to the individual's career capital). In addition we suggest that perceptions of the utility of IA career capital will contribute to the recognition of the economic value of IA. Therefore the positioning of an IA by organisational representatives and the perceptions of assignees themselves will shape the symbolic capital, the career capital and ultimately the human capital attributed to IAs.

\section{Method}

Bourdieu (1986) advocated a grounded approach to research through the collection of empirical evidence. Our present study was exploratory and attempted to uncover the symbolic capital associated with IAs. In order to encompass both the individual circumstance and organisational context within which the international experience was realized and to which the individuals returned on repatriation, the research focus was a single 
organisation. This facilitated an analysis of the perceptions of organisational representatives, company policy and individual assignees' perceptions. Policy documentation and in-depth interviews with key staff involved in the development and deployment of strategy and policy for international working contributed to this assessment. Individual experiences of IA's were explored through in-depth interviews with repatriates. The case study methodology allowed a detailed exploration of the organisational stance on IA and career development alongside an indepth analysis of individuals' perceptions and experiences of IA within the company. The study adds value by including a temporal dimension. The participants were repatriates who had returned (between 4 months and $51 / 2$ years following expatriation) and remained within the case company, which allowed an exploration of the potential pay-offs and capital of an IA which become apparent in the medium to longer term (Dickmann and Doherty, 2007).

\section{The case organisation}

The case company was from the financial services sector which provides a distinctive context for the study of careers and in particular for the examination of international careers. It has been suggested there are sectoral variations in how international strategies have been pursued and the internationalization of financial services has followed a distinct pattern (Whitely, Morgan, Kelly and Sharpe, 2003). Career management, particularly within the financial services sector, historically became a 
powerful mechanism for the establishment and monitoring of the internal labour market and for the motivation and governance of the individual employee (McKinlay, 2002). Career development within financial services grew to embody a shared destiny of individual and organisation and resulted in the development of processes and systems geared to create clear career structures and manage not only the behaviours but also the attitudes of employees (Tempest, McKinlay and Starkey, 2004).

The case company has an enduring history of international working. Fundamental to the business strategy is people and proactive talent management, supported by the organisations' capability framework. The company stresses the importance of providing senior management with the opportunity to gain international experience as a key capability in addressing the global environment and as a strategic investment in the future of the organisation. The CEO has reinforced this by stating that senior executives of the future need sufficient experience of working abroad to be familiar with the demands of running a global organisation.

\section{Sample}

From the organisational database of a population of 135 expatriates who had returned from assignment between 1998 and 2004, a sample of individuals was identified and invited to participate $(n=13)$. Non-probability sampling was used that was neither random nor claimed to be fully representative of the total population (Borman, LeCompte and Goetz, 
1986). We used purposeful strategies to intentionally select diverse cases taking note of gender, personal status on assignment, length of IA experience and managerial level. The final sample provided a varied group of just under $10 \%$ of the population of repatriates who were still within the company (Appendix 1. contains sample details).

A combination of face-to face in-depth interviews by the authors and oneto-one in-depth telephone interviews were conducted between November 2004 and February 2005. Thirteen individuals provided information on their individual experiences as a repatriate within the organisation. Additionally, two HR experts with responsibility for strategy, policy and practice for international assignments gave detailed input on the organisational view of expatriation. Three repatriates who were senior managers with some HR responsibility also provided input on HR related issues. The data set comprised HR perspectives $(n=5)$ and individual expatriation and repatriation experiences $(n=13)$.

A semi structured interview schedule was used as the basis for the interviews. A priori frames of reference were based on a review of previous research on the barriers to mobility and use of acquired skills from IAs. Questions explored the decision to expatriate, probing which themes were more or less influential e.g. professional development, organisational expectations, family and career impact. Further questions explored the perceived benefits of expatriation for individuals personally and for the organisation. These questions were informed by Bourdieu's 
(1986) forms of capital classified as Economic (financial impact), Social (impact on networks), Cultural (impact on capabilities) and Symbolic capital (perceptions of kudos, status and standing attributed to the IA). Interviewees were also asked to reflect on the repatriation process, use of expertise on re-entry into the home organisation and the overall impact of IA on career development and career prospects. Interviewees were asked to articulate the IA deal as positioned by the company and comment on the capital associated with IA from the organisational perspective. (Sample questions are included at Appendix 2).

Each interview was taped and transcribed. The analysis used a preliminary coding frame derived from the a priori frames of reference which informed the interview questions (Ritchie and Spencer, 1994). A computer assisted qualitative data analysis system (QSR NVivo) facilitated in-depth analysis, comparison of accounts and emerging themes. Lists of 'nodes' were created representing the themes identified from the interview material. Through an iterative process of analysis and review, the data were structured by recurrent patterns and organized into analytical themes. The data were mapped onto the categories of capital as outlined above (Bourdieu, 1986). As interviews were added into the coding process categories were reformed and revised until the number of new nodes added with each interview reached saturation point. Thematic representation of the data also facilitated the extraction of references and comments direct from interviews (as outlined in italics below). The data within each theme were quantified for frequency of occurrence and 
Exposing the symbolic capital of international assignments.

positive or negative inference. In addition to the two authors, a senior manager responsible for international assignments from the study organisation reviewed the veracity of the findings. 


\section{Findings}

The data from this study are organized by 3 themes. These themes illustrate the key topics revealed by the research and contribute to a more finely tuned understanding of the symbolic capital attributed to an IA experience and to career capital.

- The first theme considers perceptions of the IA deal, how it is positioned formally by the organisation, how it is articulated and understood by organisational representatives and assignees

- The second theme explores the perceived symbolic capital of the IA experience

- The third theme explores the symbolic capital of IAs in relation to career capital

\section{Theme 1: $\quad$ The perceived symbolic capital of the IA deal}

In order to set the context within which IAs are accessible, the organisational strategy, policy and practice were reviewed. A detailed framework for integrating the critical aspects of secondment management provides guidance on resource planning, recruitment and selection, preparation, on-assignment and repatriation elements of the secondment cycle. A talent management strategy had been developed in 2002, which identified the top talent pool within the organisation, for which there is an explicit expectation of having some international exposure. The international secondment policy positioned international experience as 
necessary for talent development in the Company. This policy aimed to create transparency in meeting the business objective of attaining competitive advantage through the development of an international outlook and attitude. International working was considered an essential element in building international cohesiveness, positioning IA as an objectively stated career asset within the organisation.

An analysis of senior management perceptions of what constituted the IA deal provided insights into the subjective perceptions of the symbolic capital attributed to IA within the company. For these individuals the perception of IAs was as career enhancing for the individual and as a key mechanism for the development of our talent. This was the primary deal. A secondary element was articulated as some financial incentive (Male, Senior Management). Although, there is no specific documentation on how an international secondment fits into career. We talk about it being an important thing to have as part of your career path (Male, Senior Management).

There was an appreciation that if you are going to get to the top then you need to have international exposure within the organisation which supports your chances of progression (Male, Senior Management). However, a few managers regarded being part of the talent pool as neither overt nor celebrated....there is naturally some kudos that comes with being in a talent pool we are giving them access to networks and contacts with people and access to senior management but we're not really doing it as a 
badge of honour (Female, Senior Management). A top manager with international experience suggested that there is a subjective impression that people who are taking on the more senior positions are people who have had or are having international exposure (Male, Top Management). One interviewee indicated that doing an international assignment is perceived as one hurdle on the senior management career track some would say it is a stripe on the shoulder in that, to get to the top you need to experience an IA, by doing that some would say that gives me an entry card, others might look at it saying well at least it takes away the negativeyou haven't done it (Male, Senior Management).

In terms of the international mobility policies and practices, there was a perceived lack of clarity about how process such as selection or career management were managed. One respondent explicitly mentioned a lack of clarity about selection for assignment there's still a bit of a mystery about how you get a posting" (Female, Middle Management). The HR representatives speculated that his may have been due in part to the semicovert nature of talent management within the company. One interviewee suggested that in order to attract individuals to accept an assignment the benefits need to be specific to the individual, to where it fits into their career path. (Male, Senior Management). These data would suggest that the organisational positioning of IA as part of the international career deal has a potentially significant impact on the perceived symbolic capital associated. HR representatives were in agreement that the career benefits would not necessarily be obvious at the outset of an assignment. 
In summary, there are three key themes emerging with respect to how the IA deal is positioned formally by the organisation and how it is understood by individuals. First the firm attempts to formally position the career deal associated with working abroad as positive and career enhancing. Second, while the organisational positioning of IA as part of the international career deal has a potentially significant impact on the perceived symbolic capital of IA, there remains some uncertainty in the minds of individuals about the extent to which IAs are imbued with symbolic capital by the organisation. Although there has been an explicit policy on IA as a key developmental tool, there are varying degrees to which this is understood and valued by and within the organisation. Third, the IA deal is evolving as articulated by one senior manager the process of international secondment is institutionalized to a degree and there is now (in 2005) an awareness of how to deal with those coming back (Female, Senior Manager) though this is still evolving. 


\section{Theme 2: The symbolic capital of the IA experience}

Overall, seven interviewees explicitly indicated that there was symbolic capital associated with the IA experience. The international experience was perceived to facilitate the development of cultural capital, i.e. the ability to enhance their lifestyle, knowledge and skills. In addition, symbolic capital was attributed to the development of social capital from the international assignment experience (the development of relationships, resources and the added value of these relationships through networking). Within the organisation, network development was perceived as significant symbolically I think that people do expect and it does happen that you have a much wider network by virtue of your international secondment and they kind of recognize that (Male, Senior Management). Taking advantage of the networking opportunities was perceived as important symbolically as it showed that I was on their (senior management) wavelength. So symbolically it made a big difference (Female, Senior Management). Another senior manager endorsed this view I think if anything, it's the network I guess that people respect, admire, I think that's the main symbol (Male, Senior Management). The value of the networking extended beyond the organisational context as there is a certain positive recognition value attached to the fact that you have moved around, lived and worked and experienced different parts of the world, people find you more attractive, a kind of recognition (Male, Senior Management). 
Five of the interviewees explicitly perceived the IA to hold symbolic capital in terms of enhanced career prospects. One senior manager came to the organisation specifically for an expatriate experience and found that the IA experience led to massively enhanced career prospects (Male, Senior Management). This was corroborated by others, including a top executive who commented that I think there is no doubt that I would not have achieved what I have achieved today, had I not gone on IA (Male, Top Management). Another senior manager commented that when the organisation started to promote the fact that you have to do an overseas posting, I'd been there and done it so I think there was a lot of symbolic capital (Female, Senior Management) and IA held a definite cachet I think there is some kudos in having worked abroad, it is regarded as a positive item on your career. I doubt I would be doing my kind of job had I not had the benefit of overseas experience (Male, Top Management).

In summary, the symbolic capital of the IA therefore focused on the development of skills and networks and for some senior managers, the international experience held symbolic capital in that it could leverage career progression and advancement within the organisation. Having done an IA individuals perceived that they had acquired valuable skills, knowledge and abilities, that they were more highly regarded by the company and therefore anticipated challenging work, accelerated career progression, promotion and potentially greater financial reward on return to home base. 


\section{Theme 3: The symbolic capital of IAs and career capital}

The symbolic capital of IAs and the acquisition and utilization of career capital were explored both as subjective perceptions of outcomes and objective outcomes e.g. promotion and career advancement. Four key issues emerged within this theme. These were first, the management of the expectations of expatriates, second the position offered on return, third, the career impact of the first position on return and fourth the longer term career impact of the IA.

\section{Management of expectations}

The comment of a top manager illustrated how the perceived symbolic capital of IA was manifested you think, I must be more valuable to the organisation than I was before and so your expectations are up and you are expecting to get promoted and you are expecting to get a job that is clearly better, bigger and higher up the ladder (Male, Top Management). Managing expectations was considered essential from an organisational perspective. One senior manager commented "often a returning expatriate will have a much higher expectation than you're able to fulfil and sometimes unrealistically high expectation of their own ability" (Male, Senior Management). A personal reflection supported this view sometimes your expectations are greater than the organisation is prepared to think (Male, Top Management) so in order to achieve a positive outcome for 
both organisation and individual you've got to manage people's expectations (Male, Senior Management).

Position on return

Within this organisation, the lack of a defined role on return and the lack of opportunity to use the skills acquired whilst on assignment, were recurrent themes. This study found that seven of thirteen repatriated interviewees $(n=7 / 13)$ did not have a job or a defined role to come back to. Some of the statements elicited in the interviews were I still don't have a job description [4 months after return] (Male, Middle Management). The week before I was leaving, I had no job to come back to in the UK (Male, Top Management), and there was no role (Female, Senior Management).

The lack of a role may in part be due to planning for repatriation not panning out, where individuals can return to a project type posting if a suitable position is not available immediately upon repatriation. From the organisational perspective, although policies and systems are in place to manage repatriation, re-integration can still be difficult. One senior manager articulated the state of practice - What should happen is that there should be regular contact maintained with every expatriate by a business sponsor about what skills have they developed and what's changed about them. What does happen is that they're forgotten about until 4 or 5 months before they're due back (Male, Senior Management). Clearly this led to a difficult return for some repatriates and a perceived 
lack of value attributed by the company, which negatively influenced the symbolic capital of international working.

The career impact of position on return

The organisation has formal processes and systems in place to manage the expatriation cycle, to ensure that individuals are tracked and re-entry managed. However, as illustrated above some individuals experience a difficult repatriation phase which can contribute to a career hiatus. For four interviewees $(n=4 / 13)$ the first post on return contributed to what was termed a "career wobble" (Doherty and Dickmann, 2007). One top manager commented I could have benefited more in the short term, by staying here (in the UK) because on both occasions I had a slight wobble on the way back in" (Male, Top Management). The career wobble was characterized by a role which was not well defined or not congruent with the individual's career trajectory, post assignment. A senior manager indicated that in terms of career progression it hasn't made any difference and that's where I'm greatly disappointed and the reason I say that is you go on your posting overseas and then literally you're dropped back into the ocean when you come back (Female, Senior Management).

The career wobble may be symbolically significant as repatriates are not able to realize the career benefits of the IA immediately on return. A possible corollary of the "career wobble" is that there are missed opportunities to capitalize on the skills acquired while on IA. The onus 
appeared to be on the individual to promote the career capitals they have developed. Five $(n=5 / 13)$ interviewees commented on the lack of impetus from the company I made more of it than they (the organisation) did (Male, Senior Management), I don't think there was a conscious effort on the part of my boss or the organisation, to really use any of the expertise that I had gained (Male, Senior Management) and I don't think the organisation has really got value out of my posting (Female, Senior Management).

The repatriation experience was perceived not to have an immediate positive outcome on return. This can potentially result in a reduction in the symbolic capital attributed to IA as it was not perceived to be highly valued by the company or contribute an immediate career benefit.

Long-term career benefit

For those interviewees who experienced a "career wobble" it did seem temporary. Three (out of 4 of the individuals who mentioned it) were able to get back on track within a year, or certainly in the next position within the organisation as indicated by the following comments. One senior manager indicated that People might not get the best job when they first return, but they make sure they get a much better job on the second one (Male, Senior Management). A top manager reported that a permanent position didn't really materialize for about a year (Male, Top Management), which was re-iterated by another senior manager who said 
it took me about a year to get back to where I was (in terms of career progression) (Female, Middle Management).

These observations indicate a time lapse in the symbolic capital triggered by the IA. The temporal element of repatriation has attracted limited attention and where work has been done it has highlighted considerable variations in the repatriation adjustment process with respect to performance on return and satisfaction and commitment to the company (see Eschbach et al. 2001; Sánchez et al, 2007).

Few organisations gather data about the career impact of IA, the performance or promotion of internationally experienced employees. Where organisational data have been collated it was suggested that promotion prospects on return from assignment vary considerably with less than a quarter of repatriates achieving promotion in the first year of repatriation (Dickmann, Doherty and Johnson, 2006). This apparent time lapse may impact on the perceived symbolic capital gained from the IA.

In summary, these data suggest that the management of expatriate expectations, the repatriation process and conscious planning to enable repatriates to use their acquired skills and career capital are central to perceptions of the symbolic capital of an IA experience. In the following section we will discuss the findings, draw out implications, present conclusions and develop propositions for areas meriting further investigation as highlighted by the current research. 


\section{Discussion}

This study was exploratory and attempted to ascertain the symbolic capital associated specifically with traditional IAs. This was not a definitive study but rather a descriptive, in-depth analysis of one organisation with an established history of traditional expatriation as a keystone in the business strategy and as a developmental tool for management. Given that this company has a long standing history of using IAs it provided a distinctive context for the study of careers and in particular for the examination of international careers. We acknowledge the limitations of the case approach, however there is little published material which considers the use of IAs from a symbolic capital perspective and the findings of this study do highlight some key areas meriting further exploration. We therefore explore the current findings and develop propositions for further study which would benefit from the use of a capital approach in analysis, to more fully understand the international careers arena, within a broad theoretical framework.

According to lellatchitch et al (2003), and Mayrhofer et al (2004b) perceptions of symbolic capital are fundamental to the development of career capital. In the organisation studied, IAs were positioned, from the corporate perspective, as key to the development of the business and as important to career progression for those people destined for high-ranking managerial positions within the company. In this case the IA was 
symbolized objectively by the company in a way that signaled status and could increase prestige by facilitating career progression. It has been proposed that the making of career capital involves processes of internal and external recognition which contribute to the symbolic and career capital accrued (lellatchitch et al, 2003 and Mayrhofer et al, 2004b). Based on the issues raised by the current study, around the organisational positioning and the potential impact on the perceived symbolic capital and career capital of IAs, Figure 1 builds a model of the development of career capital from an international assignment.

[Insert Figure 1 here]

Many elements which support an international career within an organisation can be construed as highly symbolic, for example, being identified as part of a talent pool, the kudos of being abroad, the extensive support and financial investment bestowed on an individual undertaking an IA. In addition to the potential career benefits which form part of the IA deal, all can be understand as symbolic acts. At the time of the research the membership of talent pools remained sometimes covert within this organisational context, which appeared to have led to some lack of clarity about the symbolic capital imbued by the organisation. In addition, although the organisational processes and mechanisms for managing the logistics of IAs were clearly and openly documented, the implementation of these processes was sometimes unclear. This may have contributed to some perceived ambiguity about how individuals were selected for IA and 
added to an aura of uncertainty about the symbolic capital of IAs. These findings would suggest that for careers within organisations and in particular with respect to IA, context has an important impact on how employees experience an international assignment (Dickmann and Doherty, 2007) and therefore on the creation of symbolic capital.

As outlined in Figure 1. the development of symbolic capital impacts the process of recognition of the economic utility of career capital, which is also shaped by the organisational processes in place, not least the management of repatriation and the ability to use the skills that had been acquired while on assignment. Where individuals did not have a defined role to return to this led in some cases to a career "wobble" or hiatus in their expected career progression, certainly in the short term (Doherty, Dickmann and Brewster, 2006; Doherty and Dickmann, 2007). The perception that there were missed opportunities to use the skills that had been acquired on assignment suggests that there may also have been missed opportunities to reap the benefits of the international experience for the organisation and ultimately its human capital. Where there is a lack of symbolic capital associated with IA and repatriates are attributed little recognition of the capital acquired, the ability to translate the individual career capital into organisational human capital may be compounded.

Although positioned as business critical by top management there was varied opinion at a senior management level about the symbolic nature of the international deal. Thus, symbolic recognition of the utility of an IA to 
the organisation or its contribution to the business bottom line were not so strongly apparent as suggested by previous authors (Lazarova and Caligiuri, 2001, Carpenter et al, 2000, Carpenter et al, 2001),

The notion that symbolic capital operates as a limited resource (Flint and Rowlands, 2003) is pertinent to the current findings. The mechanisms used to identify and manage individuals who have the potential to become senior management are instrumental in setting the limits on these elite, while organisational structure influences the individual's ability to advance. Within this organisation, IAs are portrayed as an important and advantageous component of a senior management career path, one "hoop" (Male, Senior Management) that people are required to jump, to indicate their suitability for senior management. The research indicated that international experience is a necessary but not sufficient condition to progress to the senior management echelons of the company completing an IA does not guarantee a promotion.

International assignees clearly perceived the benefits of an expatriate assignment and these were obvious particularly for cultural and social capital. For individuals in this study the symbolic value of the IA deal was rooted in the perceived benefits as an enhancing personal developmental experience. Individuals who had completed an IA indicated that there is some recognition by others of the value of their experience. However, the implicit nature of the IA deal may have contributed to an apparent dilution of the perceived symbolic capital of the IA to the organisation. 
This research indicated that recognition of the symbolic capital of IAs is facilitated through the management of expectations, the repatriation processes and career planning on return. (Table 1 provides a synopsis of the factors impacting the development of symbolic capital from international assignments). It may be argued that any of the career capitals accumulated from the assignment, such as networks, skills and abilities are attributed symbolic capital only if they are seen to be valuable in the role and work the individuals is doing on repatriation. The literature to date has highlighted a key area of dissatisfaction for repatriates, in the lack of opportunities to use the skills acquired while on assignment. This has been quoted as a factor prompting intention to exit by the returned expatriate (Suutari and Brewster, 2003) and therefore loss of the potential return on investment in human capital terms (Doherty and Dickmann, 2005)

[Insert Table 1. here]

This study found that the expectations of expatriates were sometimes higher than the organisation could meet. Policy clearly guided how the secondment process should be managed, however this process did not always run smoothly, leading to some dissatisfaction among those returning from assignment, particularly where individuals did not have a position on return in which they perceived opportunities to exploit the capabilities developed on assignment. Rather some experienced a career "wobble", which may have contributed to a lack of symbolic capital from IA. 
In addition to the career "wobble" notion there appeared to be an emphasis on individuals to promote their own career capital on return to the home base, the opposite emphasis from the high degree of organisational support provided for the management of IA. Previous authors have emphasized the need for the organisation to make explicit the symbolic capital of international experience in order to promote the value of such experience (Carpenter et al, 2001, Lazarova and Caligiuri, 2001).

lellatchitch et al (2003) suggested that it is the process of recognition of the symbolic capital of career which is fundamental to the usefulness of career capital in economic terms. For the current case organisation there is a degree of ambiguity about the IA deal for individuals, which may in part be attributed to the semi-covert process of talent management. The temporary career wobble experienced by some individuals impacted on the lack of an immediate, direct career benefit. This may have signalled that symbolically the IA deal may have limited career capital potential immediately upon repatriation. Individuals often seem to strive to create for themselves the opportunity to use their acquired skills, as the company may have limited insights into how to capitalize on the knowledge, skills and capabilities they have developed.

The process of external recognition of the usefulness of career capital ultimately links to the human capital of the organisation. If the career capital built up from an international experience can be applied and used 
within the company on repatriation, this adds to the pool of skills, knowledge and abilities within the organisational human capital portfolio. There appears to be a difference in emphasis between the individual level capital acquired and the organisational level capital attributed to an IA.

This paper contributes to the careers research literature and debate, by using the concept of symbolic capital to explore the accumulation of individual career capital through IAs. It uses an integrated career perspective that allows the capture and contrast of both organisational and individual perceptions of the nature and effects of long-term work abroad. Using the concept of symbolic capital has contributed to a more discerning picture of international careers within an organisational context. A range of further areas of exploration have also been revealed which would benefit from exploration in larger, more diverse populations.

The current data suggested that the process of recognition of the symbolic capital of IAs is context dependent; mediated by the organisational positioning and management of the expatriation process. Further exploration of the organisational representation of the IA deal is an important area for research which may usefully explore the impact of the extent to which the IA deal is explicit about the symbolic value which will be attributed to individuals. The potential schism between individual perceptions of the symbolic capital of IAs and the perception of those representing the organisational position is a key area which merits further exploration. 
Proposition 1: Explicit positioning of the value of IAs by organisations is instrumental in aligning individual expectations of the symbolic capital associated with IAs

As suggested by Bourdieu (1986) a key element in the development of symbolic capital is the process of recognition of the capital associated and how recognition is signaled. Modelling the making of career capital lellatchitch et al, (2003) and Mayrhofer et al, (2004b) suggested that within the career field, symbolic capital, determines the usefulness of career capital in economic terms. Our research used these insights and went beyond their discussion to look at these complex relationships in more depth, locating individuals in the context of return to and continued employment in the same organisation after an IA. By highlighting that the process of recognition of the symbolic capital of IAs appears to be mediated by the management of expectations in tandem with the management of the repatriation process, the selection of the position on offer and individual career pro-activity our work provides useful insights into the longer-term impact of IA. Managing expectations was explicitly acknowledged as important to the IA experience, both from an organisational and individual perspective.

Proposition 2: Formal endorsement of IAs as important to the organisation and to individual career development will result in greater individual perceived symbolic capital associated with IAs. 
The results of our study suggested that individual expectations of the symbolic capital attributed to an IA by the organisation are centrally important in shaping perceptions of increased career capital as a result of the experience. Perceived symbols of recognition from the individual perspective included a defined job, challenging work, opportunities to use the skills acquired on assignment and career advancement on repatriation.

Individuals have diverse expectations of repatriation and their career progression, as a result of international working. Different organisational contexts are likely to shape the expectations of individual assignees. Thus, the psychological contract of international assignees is likely to be rather diverse, so the management of their expectations and their repatriation is highly complex and often viewed as unsatisfactory (Stahl et al., 2002). A useful starting point for the management of the psychological contract surrounding the return of expatriates would be to identify their motivations to go abroad (Dickmann and Doherty, 2007) and their expectations upon return (Stahl and Cerdin, 2004). Understanding the organisational context and the degree of (non-) alignment with individuals can give valuable insights to inform the management of the psychological contract (Conway and Briner, 2005). HSBC, the bank, has approached this through drawing up mechanisms to bind individuals to their home countries, to link them to sponsors and to have expectation management conversations with mentors and superiors (Dickmann and Harris, 2005). 
Proposition 3: The greater the degree of symbolic capital associated with IAs, the more enhanced career progression will result for repatriates

There is as yet a lack of research which considers the impact of different organisational contexts on the development of symbolic capital for IAs. Further research could beneficially examine the development of symbolic capital of international working and how symbolic capital is translated into career capital in different organisational contexts.

Proposition 4: Different organisational contexts will have a distinct impact on the development of symbolic capital for IAs.

\section{Conclusions}

Our work drew on the notion of capital and in particular symbolic capital, as this concept enabled a fuller understanding of the current issues involved in researching individual career capital accumulation and the links to its utilization in a global context. It goes beyond the current static focus in research on IA to include a longer-term perspective on the perceived outcomes of IAs. This work provides a platform for further research on the utility of the concept of symbolic capital to our understanding of career issues and in particular how it may be instrumental in the evolution of career capital. Also, given that there is now a proliferation in the variety of forms of international working, there are many avenues to pursue in the 
exploration of the short and long term impacts of such working practices on individuals' careers and ultimately the symbolic and actual contribution that any international experience can make to organisational success. Due to the exploratory nature of the research, more questions were raised than answered. A series of propositions were developed which can contribute to the development of explanatory and normative theory in this field.

The study was limited by a focus on data collection from one context. However, this was an exploratory study in which context was considered to be a potentially important variable. The sample was small and not selected to be representative, but rather to provide data on IA experiences to including a diverse range of work and career themes. The interview methodology used measures of self reported capital accumulation which relied on retrospective memory of motivations and evidence. The analysis also relied on the interpretative nature of what constitutes symbolic capital. The reader is therefore urged to consider these limitations when interpreting the findings of the study.

There is a range of managerial implications in relation to symbolic and career capital management. Among these are the effective alignment of organisational and individual expectations which requires employers to have a transparent and consistent rationale for the selection, preparation, support, performance management and repatriation of international assignees. Symbolic capital can play a central role in this process generating either positive or negative perceptions depending on how 
successful the company is at achieving consistency in this alignment. There needs to be an understanding of the motivations of international assignees and the potential career capital impact of working abroad. Armed with this knowledge companies can consider the type of job, role and responsibilities the individual could take on repatriation. Companies should also facilitate individuals to consider these issues before embarking on an IA. There are long term learning and career impacts of working abroad. Both in their personal and work related contexts an individual with foreign work experience may be viewed and valued differently by their peers who lack this experience. The authors suggest that even in the current, dynamic work environment companies would be well advised to factor the symbolic capital effects into their long-term career planning and leadership succession.

Our work provides a platform for further research on the utility of the concept of symbolic capital to our understanding of career issues and in particular how it may be instrumental in the evolution of career capital. Also, given that there are now a variety of different forms of international working, there is a need to understand the processes underpinning the short and long term impacts of such working practices on individuals' careers and ultimately the symbolic and actual contribution that any international experience can make to individual and organisational success. 


\section{References}

Black J S. and Gregersen H. B. (1992) "Towards a theoretical framework of repatriation adjustment", Journal of International Business Studies 4, $737-760$

Black, J. S. and Gregersen, H. B. (1999) 'The right way to manage expats', Harvard Business Review, March/April, 52-61.

Borman, K.M., LeCompte, M.D., and Goetz, J.P. (1986), "Ethnographic and Qualitative Research Design and Why it Doesn't Work," American Behavioral Scientist, Sept/Oct, 30(1), 42-58.

Borstorff, P.C., Harris, S.G., Field, H.S., and Giles, W.F. (1997), "Who'll Go? A Review of Factors Associated with Employee Willingness to Work Overseas," Human Resource Planning, 20(3), 29-40.

Bourdieu, P. (1977), Outline of a Theory of Practice, Cambridge, MA:

Cambridge University Press.

Bourdieu, P. (1986), "The Forms of Capital" in Handbook of Theory and Research for the Sociology of Education, eds. J.C. Richardson, London: Greenwood Press, pp. 241-258.

Bourdieu, P. (1998), Practical Reason. On the theory of action, Stanford, CA: Stanford University Press. 
Carpenter, M.A., Sanders, W.G., and Gregersen, H.B. (2000), “IA

Experience at the Top Can Make a Bottom-line Difference," Human Resource Management, 39(2/3), 277-285.

Carpenter, M.A., Sanders, W.G., and Reverse, H.B. (2001), "Bundling Human Capital with Context: The Impact of IA Experience on Multinational Firm Performance and CEO Pay," Academy of Management Journal, 44(3), 493-511.

Cerdin, J. L. and Dubouloy, M. (2004), "Expatriation as a Maturation Opportunity. A Psychological Approach Based on Copy and Paste", Human Relations, vol. 57, no. 8, 957-981.

Conway, N., and Briner, R. (2005), Understanding Psychological Contracts: A critical evaluation of theory and research, Oxford: Oxford University Press.

Cronin, B., and Shaw, D. (2002), "Banking (on) Different Forms of Symbolic Capital," Journal of the American Society for Information Science and Technology, 53(14), 1267-1270.

Cullinane, N., and Dundon, T. (2006), "The Psychological Contract: A critical review," International Journal of Management Reviews, 8(2), 113129.

Dany, F., Mallon, M., and Arthur, M.B. (2003), "The odyssey of career and the opportunity for international comparison," International Journal of Human Resource Management, 14(5), 705-712. 
Dickmann, M., and Harris, H. (2005,) “Developing career capital for global careers: The role of international assignments," Journal of World Business, 40(4), 399-408.

Dickmann, M., Doherty, N. and Johnson, A. Measuring the Value of International Assignments. Report for PwC UK Geodesy. Cranfield School of Management, December 2006

Dickmann, M., and Doherty, N. "Exploring the Career Capital Impact of International Assignments within Distinct Organizational Contexts," British Journal of Management, Forthcoming 2007. Published article online: 22Jun-2007

Dickmann, M., Doherty, N., Mills, T. and Brewster, C. "Why do they go? Individual and Corporate Perspectives on the Factors Influencing the Decision to Accept and International Assignment." International Journal of Human Resource Management Forthcoming 2008

Doherty, N., and Dickmann, M. (2005), 'The Symbolic Capital of International Assignments: Linking Career Capital Accumulation to Human Capital Utilization'. Presented at the 21st EGOS Colloquium, Berlin.

Doherty, N., Dickmann, M., and Brewster, C. (2006), 'Using the Career Capital of International Assignments Back Home. The "Career Wobble”'. Paper presented at the British Academy of Management Conference, Belfast. 
Doherty, N. \& Dickmann, M. (2007) Managing the career wobble of repatriates Developing HR Strategy 15:17-21

Dowling, P.J., Welch, D.E. and Schuler, R.S. (1999) 'International Human Resource Management. Managing People in a Multinational Context', Cincinnati, South-Western College Publishing.

Edstrom, A. and Galbraith, J. R. (1977), "Transfer of managers as a coordination and control strategy in multinational organizations", Administrative Science Quarterly, Vol. 22, No. 2, pp. 248-263.

Everett, J. (2002), “Organizational Research and the Praxeology of Pierre Bourdieu," Organizational Research Methods, 5(1), 56-80.

Flint, J. and Rowlands, R. (2003), "Commodification, normalization and intervention. Cultural, social and symbolic capital in housing consumption and governance," Journal of housing and the Built Environment, 18(3), 213-232.

Fuller, T., and Tian, Y. (2006), "Social and Symbolic Capital and Responsible Entrepreneurship: An Empirical Investigation of SME Narratives," Journal of Business Ethics, 67, 287-304

Gergs, H. (2003), "Economic, Social, and Symbolic Capital", International Studies of Management \& Organization, vol. 33, no. 2, 22-48.

Guest, D. E. (1998), "Is the psychological contract worth taking seriously?", Journal of Organizational Behavior, vol. 19, 649-664. 
Herriott, P., Manning, W. E. G. and Kidd, J. M. (1997), "The Content of the Psychological Contract", British Journal of Management, vol. 8, 151-162.

lellatchitch, A., Mayrhofer, W., and Meyer, M. (2003), “Career fields: a small step towards a grand career theory?," The International Journal of Human Resource Management, 14(5), 728-750.

Inkson, K, Arthur, M, Pringle, J \& Barry, S. (1997). Expatriate assignment Versus Overseas Experience: Contrasting Models of international Human Resource Development. Journal of World Business, 32 (4) pp.351-368 Johnson, G., (1990), "Managing Strategic Change; the role of symbolic action," The British Journal of Management, 1, 183-200.

Larçon, J.P., and Reitter, R. (1984), "Corporate imagery and corporate identity" in The irrational executive. Psychoanalytic explorations in management, eds. M. Kets de Vries, New York, NY: International Universities Press.

Larsen, H.H. (2004), "Global career as dual dependency between the organisation and the individual," Journal of Management Development, 23(9), 860-869.

Lazarova, M., and Caligiuri, P. (2001), "Retaining Repatriates: The Role of Organisational Support Practices," Journal of World Business, 36(4), 389401.

Mayrhofer, W., Meyer, M., Steyrer, J., Maier, J., Langer, K. and Hermann, A. (2004a), 'International Career Habitus - Thick Descriptions and 
Theoretical Reflections'. Paper presented at the Academy of Management Annual Meeting Symposium on Global Careers and Human Resource Development: Emerging IHRM Perspectives New Orleans, USA.

Mayrhofer, W., lellatchitch,A., Meyer, M., Steyrer, J., Schiffinger, M., and Strunk, G. (2004b), “Going beyond the individual. Some potential contributions from a career field and habitus perspective for global career research and practice," Journal of Management Development 23(9), 870884.

McKinlay, A. (2002), "Dead Selves: The Birth of the Modern Career," Organization 9(4), 595-614.

McNulty, Y.M., and Tharenou, P. (2004), ‘Expatriate Return on Investment', Academy of Management Best Conference Paper IM: F4.

McNulty, Y. \& Tharenou, P. (2004), Expatriate Return on Investment: A Definition and Antecedents, International Studies of Management and Organisation, 34(3): 68-95.

Moingeon, B., and Ramanantsoa, B. (1997), "Understanding corporate identity: The French school of thought," European Journal of Marketing, 37(5/6), 383-395.

Özbilgin, M., and Tatli, A. (2005), "Book Review Essay: Understanding Bourdieu's Contribution to Organization and Management Studies," Academy of Management Review, 30, 4 855-877. 
Ritchie, J., and Spencer, L. (1994), "Qualitative data analysis for applied policy research," in Analysing Qualitative Data, eds. A. Bryman, and R.G. Burgess, London: Routledge.

Rousseau, D.M. (1995), Psychological Contracts in Organisations, Sage, Thousand Oaks, CA.

Sparrow, P., Brewster, C., and Harris, H. (2004), Globalizing Human Resource Management, Routledge: London.

Stahl, G.K., Miller, E., and Tung, R. (2002), "Toward the boundaryless career: A closer look at the expatriate career concept and the perceived implications of an IA," Journal of World Business, 37, 216-227.

Stahl, G., and Cerdin, J.-L. (2004), "Global Careers in French and German Multinational Corporations," Journal of Management Development, 23(9), 885-902.

Suutari, V., and Brewster, C. (2000), "Making their own way: international experience through self-initiated foreign assignments," Journal of World Business, 35(4), 417-436.

Suutari, V., and Brewster, C. (2003), "Repatriation: empirical evidence from a longitudinal study on careers and expectations among Finnish expatriates," The International Journal of Human Resource Management, 14(7), 1132-1151. 
Suutari, V., and Taka, M. (2004), "Career Anchors of Managers with International Careers", Journal of Management Development, 23(9), 833847.

Tempest, S., McKinlay, A., and Starkey, K. (2004), "Careering alone:

Careers and social capital in the financial services and television industries," Human Relations 57(12), 1523-1545.

Thomas, D.C., Lazarova, M.B., and Inkson, K. (2005), “Global careers: New phenomenon or new perspectives?," Journal of World Business, 40(4), 340-347.

Uhliř, D. (1998), "Internationalization, and institutional and regional change: restructuring post-communist networks in the region of Lanškroun, Czech Republic," Regional Studies, 23(7), 673-685.

Welch, D.E. (2003), "Globalisation of staff movements: Beyond cultural adjustment," Management International Review, 43(2), 149-169.

Whitley, R., Morgan, G., Kelly, W., and Sharpe, D. (2003), "The Changing Japanese Multinational: Application, Adaptation and Learning in Car Manufacturing and Financial Services," Journal of Management Studies, 40(3), 643-672. 


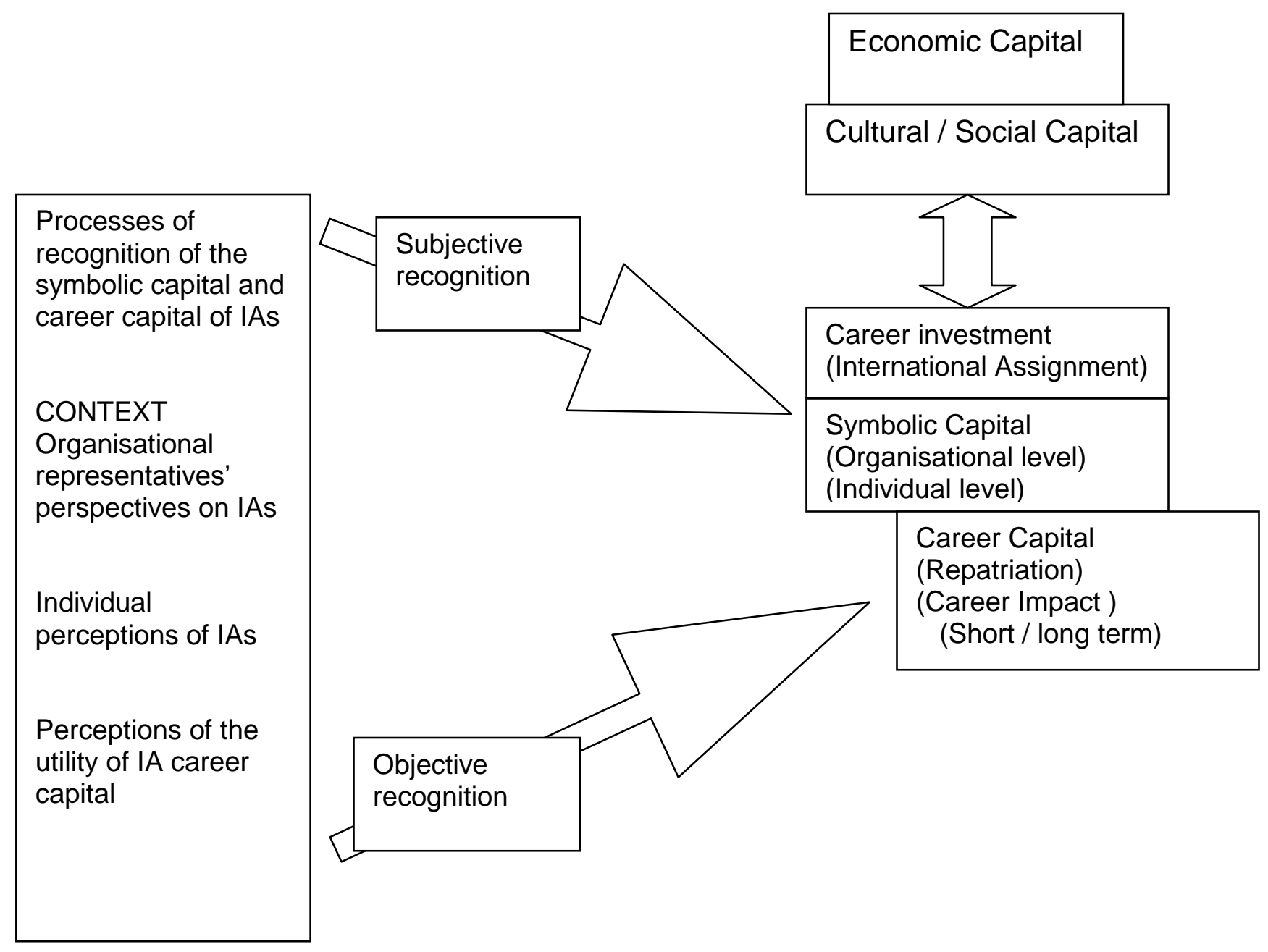

Figure 1. The development of career capital from International Asignments (after lellatchitch et al, 2003) 
Table 1. Factors influencing the development of the symbolic capital of international assignments

\begin{tabular}{|c|c|c|}
\hline & $\begin{array}{l}\text { Policies and Practices } \\
\text { which shape perceptions }\end{array}$ & Potential Symbolic Capital \\
\hline The deal & $\begin{array}{l}\text { IAs are business critical. } \\
\text { - IAs are career enhancing. } \\
\text { part of talent management. }\end{array}$ & $\begin{array}{l}\text { - Perceptions vary depending } \\
\text { on the organisational context. } \\
\text { - IAs generate kudos. } \\
\text { - IAs are positive for individual } \\
\text { career development. }\end{array}$ \\
\hline $\begin{array}{l}\text { The } \\
\text { Assignment }\end{array}$ & - IA purpose. & $\begin{array}{l}\text { - IAs develop skills and } \\
\text { networks. } \\
\text { - IAs provide an intense } \\
\text { individual experience. }\end{array}$ \\
\hline Repatriation & $\begin{array}{l}\text { - Return planning } \\
\text { - } \text { Position offered on return } \\
\text { skills use }\end{array}$ & $\begin{array}{l}\text { - } \quad \text { Management of } \\
\text { expectations. } \\
\text { - } \quad \text { Career Wobble. } \\
\text { - Use of acquired skills } \\
\text { - Leading / lagging career } \\
\text { trajectories }\end{array}$ \\
\hline $\begin{array}{l}\text { Post- } \\
\text { repatriation }\end{array}$ & $\begin{array}{l}\text { Long-term career planning } \\
\text { Succession planning }\end{array}$ & $\begin{array}{l}\text { - Career progression } \\
\text { - Value of IA experience }\end{array}$ \\
\hline
\end{tabular}




\section{APPENDIX 1 Sample details}

\begin{tabular}{|c|c|c|c|c|}
\hline $\begin{array}{l}\text { Managerial } \\
\text { Level }\end{array}$ & Gender & $\begin{array}{l}\text { IA experience } \\
\text { approx Yrs (no of } \\
\text { assignments) }\end{array}$ & $\begin{array}{l}\text { Time } \\
\text { since } \\
\text { return }\end{array}$ & $\begin{array}{l}\text { Personal status } \\
\text { on assignment }\end{array}$ \\
\hline Top & $M$ & $\begin{array}{l}7(2) \\
\text { (+organisational } \\
\text { perspective) }\end{array}$ & $4 \mathrm{yrs}$ & +Spouse +family \\
\hline Top & $M$ & $3(1)$ & $3 \mathrm{yrs}$ & +Spouse +family \\
\hline Senior & $M$ & $2.5(1)$ & 2 yrs & +Spouse +family \\
\hline Senior & $M$ & $7(2)$ & 2 yrs & +Spouse +family \\
\hline Senior & $M$ & $2.5(1)$ & $2 \mathrm{yrs}$ & +Spouse +family \\
\hline Senior & $M$ & $\begin{array}{l}3 \\
(1)(+o r g a n i s a t i o n a l \\
\text { perspective })\end{array}$ & $4 \mathrm{yrs}$ & +Spouse \\
\hline Senior & $\mathrm{F}$ & $5(3)$ & $51 / 2 y r s$ & Single \\
\hline Senior & $\mathrm{F}$ & $\begin{array}{l}7(2) \\
\text { (+organisational } \\
\text { perspective) }\end{array}$ & $4 \mathrm{yrs}$ & +Partner \\
\hline Senior & $F$ & $2(1)$ & $5 \mathrm{yrs}$ & +Spouse +family \\
\hline Middle & $M$ & $3(1)$ & $4 \mathrm{mths}$ & Single \\
\hline Middle & $F$ & $1(1)$ & $5 \mathrm{yrs}$ & +Spouse \\
\hline Middle & $\mathrm{F}$ & $2(1)$ & $3 \mathrm{yrs}$ & +Spouse \\
\hline Middle & $F$ & $3.5(2)$ & & +Spouse \\
\hline Senior & $M$ & $\begin{array}{l}\text { Organisational } \\
\text { perspective }\end{array}$ & & \\
\hline Senior & $M$ & $\begin{array}{l}\text { Organisational } \\
\text { perspective }\end{array}$ & & \\
\hline
\end{tabular}




\section{APPENDIX 2 Sample interview questions}

- What pros and cons did you consider before you accepted international work?

- How is the international assignment positioned as part of career, what is the organisation offering?

- Would you say that in your organisation an international assignment is beneficial to one's career?

- Why?

- What are the benefits (capitals) for individuals / organisation Economic - (financial) Social - (networks/relationships) Cultural - (dealing with diversity) Symbolic - (kudos, recognition, status)

- What did you learn from the international experience Capabilities (how) Networks (whom) Personal motivations (why)

- What did you think about the position / role that was offered / that you took up on return from the international work?

- How was the process of repatriation?

- How did the organisation use your expertise after 're-entry'?

- What impact has the international assignment had on your career / career prospects? 